\title{
The Memory Revolution Meets the Digital Age
}

\author{
Red Army Soldiers Remember World War II
}

\author{
by Iva Glisic and Mark Edele*
}

This essay analyzes iremember.ru - an open-access oral history collection containing more than 2,500 interviews with Soviet veterans of the Second World War. Launched in 2000 as a small grassroots project, it soon received state backing and grew into a vital element of Russia's contemporary memory landscape. The essay examines the origins of this project and its value as a historical source; just as well, it explores its evolution and the curious role it plays in contemporary Russian memorial culture. Bringing together history, memory studies, and the study of contemporary politics, the essay argues that iremember.ru provides important insights into both the Soviet experience of the Second World War and the forces that shape political discourse in Russia today.

Military life for young infantry recruit Daniil Zlatkin began on July 3, 1941. After several months of intense training, and narrowly avoiding a death sentence after being accused of stealing potatoes to supplement his meagre food rations, Zlatkin found himself boarding a railroad boxcar (teplushka) with "sixty to eighty" other men on a journey to an unknown destination. ${ }^{1}$ They would disembark to the sounds of gunfire and explosions in the village of Myshkino, near Borodino, some 150 kilometers west of Moscow - a village whose name would remain with Zlatkin for the rest of his life. That evening, a sergeant (starshii serzhant) summoned the new arrivals and demonstrated the workings of the Degtyaryov machine gun. In concluding his lesson, the sergeant asked the men to confirm that they understood how the device

* Research and writing were made possible in part by an Australian Research Council Discovery Grant (DP130101215) and an Australian Research Council Future Fellowship (FT140101100). The School of Historical and Philosophical Studies (SHAPS) at the University of Melbourne provided travel funds for a meeting of the authors. Earlier versions were presented at the SHAPS History Brown Bag Seminar on May 3, 2018 and at the Manchester-Melbourne Workshop "Memories of War in Post-Socialist Space before and after Crimea" (June 26/27, 2018), a workshop supported by the ManchesterMelbourne Humanities Consortium Fund. If not otherwise indicated, all translations by the authors. To transliterate Russian text we use the simplified Library of Congress transliteration system. See http://www.text-transliterator.com/about.html.

1 Zlatkin Daniil Fedorovich, http://iremember.ru/memoirs/pekhotintsi/zlatkin-daniilfedorovich/. Teplushka is a convoy of converted boxcars. Leslie Page Moch and Lewis H. Siegelbaum, Broad Is My Native Land. Repertoires and Regimes of Migration in Russia's Twentieth Century, Ithaca 2014, p. 7. On transportation of soldiers in teplushka see the interview with Artem Arshakovich Dzhesmedzhiian, http://iremember.ru/ memoirs/minometchiki/dzhesmedzhiyan-art-m-arshakovich/. 
worked; "Understood!" everyone yelled, but Zlatkin was sure that none of them really understood a thing. Soon they found themselves on the battlefield, under enemy fire. Zlatkin felt that each and every bullet was aimed directly at him and him alone. Suddenly aware of the full weight of equipment he was saddled with, including a machine gun barrel (stvol), a rifle, a duffel bag (veshchmeshok), a gasmask, and an axe - 32 kilograms in total - he was overcome with weakness and fell to his knees. Yet just as had he accepted his fate, Zlatkin felt a revolver at the back of his head and heard his captain screaming at him: "Scoundrel, forward! For the Motherland! For Stalin!" Managing to stand, he joined the cry of "Forward!" and started to run across a field littered with the bodies of the fallen. He looked up to see the sky thick with German planes, and in a moment of shock he tripped and fell again, still screaming "Forward! For the Motherland! For Stalin!” Before he could stand, he felt a blow to his right arm and lost consciousness. This was his first battle. It was October 15, 1941.

Historians and students of the Second World War will recognize many of the elements of Zlatkin's story. ${ }^{2}$ His experience evokes themes that arise in discussions of the Soviet Union's initial response to the German advance in the summer of 1941, from an unprepared and disoriented rank and file forced to obey foolhardy orders, to the incredible loss of life on battlefields that Soviet veterans would describe as "mince grinders" (miasorubka). ${ }^{3}$ Subsequent episodes of his story also follow a familiar narrative. Regaining consciousness, Zlatkin noticed that he had only his footwraps on, as someone from the advancing army had taken his boots. Two of his right-hand fingers were injured. He had no first aid kit, and the liquid within his gasmask that he might have used to disinfect his wounds had vanished well before he had even reached the frontline - like most soldiers, he had passed it through a filter of cement and coal, before drinking it for its alcohol. Yet Zlatkin managed to patch himself up and obtain a new pair of boots, as well as a coat and some food and water from the surrounding corpses. Together with a fellow soldier who he found alive among the piles of dead bodies, Zlatkin miraculously walked his way out of the encirclement. After enduring Soviet interrogation - the fate of anyone who managed to return from the German occupied territories - he continued to serve until May 1946. Zlatkin's account of what would come to be

2 See, among others, David M. Glantz and Jonathan M. House, When Titans Clashed. How the Red Army Stopped Hitler, Lawrence 1995; E. S. Seniavskaia, $1941-1945$. Frontovoe pokolenie. Istoriko-psikhologicheskoe issledovanie, Moscow 1995; Constantine Pleshakov, Stalin's Folly. The Tragic First Ten Days of World War II on the Eastern Front, Boston 2005; David Glantz, Colossus Reborn. The Red Army at War, 1941 - 1943, Lawrence 2005; Catherine Merridale, Ivan's War. Life and Death in the Red Army, 1939-1945, New York 2006; Roger Reese, Why Stalin's Soldiers Fought. The Red Army's Military Effectiveness in World War II, Lawrence 2011; Evan Mawdsley, Thunder in the East. The Nazi-Soviet War 1941 - 1945, London $2016^{2}$.

3 Fedorovich Stepan Georgievich, http://iremember.ru/memoirs/infantrymen/fedorovichstepan-georgievich/. 
called the "Great Patriotic War" can be read in full at the website Ia pomniu (iremember.ru), one of the largest online collections of oral history pertaining to the Soviet wartime experience. ${ }^{4}$

This collection contains more than just the standard stories. When the war broke out, Mikhail Sidorov was serving with border troops stationed in the Far East. ${ }^{5}$ Within a fortnight of Vyacheslav Molotov's announcement that Germany had attacked the Soviet Union, Sidorov was sent on a mission to build an outpost on Ratmanov Island (otherwise known as Big Diomede), a 45 square kilometer rectangle in the middle of the Bering Strait, located just four kilometers from the closest American-held territory of Kruzenshtern Island (or Little Diomede). With the war against Germany gathering pace and Soviet sea ports in the west either blocked or vulnerable to air strikes, the path to the Pacific Ocean offered a critical channel of communication with the allies. Nearly half of the tonnage of Lend-Lease aid delivered throughout the war went to Vladivostok, on ships crewed by Soviets and flying the Red flag. Another quarter each came via the Northern route from Britain to Murmansk and the Persian route through Soviet-occupied Iran. Only a small share - about three percent of all deliveries - came through the Arctic route. It began in the Pacific but instead of going straight to Vladivostok, it headed north, through the Bering Strait and all along the Arctic coast to Murmansk. It was this route Sidorov was defending. ${ }^{6}$ Sidorov was an experienced border guard, who had previously helped to secure the new border in Western Ukraine following Stalin and Hitler's division of Poland in September 1939. The cast of his island tales is the ten soldiers, two commanders and five dogs who had been designated as his command, the four civilians responsible for manning the polar station, along with Sidorov's wife, Margarita Dmitrievna, and their

4 Another major collection is the lavishly funded Blavatnik Archive, which resides in a Manhattan tower overlooking Central Park. With a focus on oral history by Jewish Red Army soldiers, the Blavatnik Archive makes a small number of interviews available as video clips: http://www.blavatnikarchive.org. It has also published one book: Julie Chervinsky et al. (eds.), Lives of the Great Patriotic War. The Untold Stories of Soviet Jewish Soldiers in the Red Army during WWII, vol. 1, New York 2011. Though much smaller in scope, Facing Stalingrad is another important online collection containing interviews with Soviet and German veterans who participated in the Battle of Stalingrad: https://facingstalingrad.com. Historian Jochen Hellbeck created the website as part of his book project: Jochen Hellbeck, Stalingrad. The City that Defeated the Third Reich, New York 2015. The online project War Witness: Heritage, developed by state-funded Russian international television network RT (formerly Russia Today) contains around 100 video clips of short interviews with Soviet veterans: http://catalog.rt.com/en/series/ war-witness-heritage/.

5 Sidorov Mikhail Nikolaevich, http://iremember.ru/memoirs/nkvd-i-smersh/sidorovmikhail-nikolaevich/.

6 Alla Paperno, Lend-liz. Tikhii okean, Moscow 1998, p. 6. On the importance of the Pacific route see also Patrick G. March, Eastern Destiny. Russia in Asia and the North Pacific, Westport 1996, p. 223. 
daughter, Alla - the first Russian girl to be born on this tiny patch of land at the end of the Soviet Union.

For tank crew member Ivan Maslov, meanwhile, the war began near the Iranian border. ${ }^{7}$ A man with substantial combat experience gained in Poland and during the Finnish War, Maslov's entry into the Second World War was initiated by the Anglo-Soviet invasion of Iran in the summer and autumn of 1941, which made Lend-Lease through this route viable in the first place. From Stepanakert in Nagorno-Karabakh Republic, his unit crossed the Iranian border and made its way to the city of Tabriz without much resistance. After reaching Tehran, his unit participated in a joint military parade with the British in front of the Shah's palace. ${ }^{8}$

Meanwhile, some 3,000 kilometers to the north-east, Iakov Krasil'shchikovGolodets learned about the start of the war near Dzhezkazgan, Central Kazakhstan, in one of the camps of the Gulag archipelago known as ITL-1. ${ }^{9}$ A son of enemies of the people, and the perpetrator of a prank gone awry that ended with a charge of robbery, Krasil'shchikov-Golodets had resided in the camp since the spring of 1940. He recalls Molotov's announcement of June 22, 1941 being played in the dining room, and the subsequent introduction of stricter protocols within the camp, including the isolation of political prisoners from other inmates and even smaller food rations. ${ }^{10}$ With the start of the war, "tranquil life came to an end" in the camps and, with no newspapers or radio, Krasil'shchikov-Golodets and other inmates came to know about the war only through rumors, each more terrifying than the last. In April 1942, he would send a letter to Stalin asking him to let him serve in the army. Although this attempt failed, Krasil'shchikov-Golodets did see frontline service after being assigned to the infantry in 1943, ten days before the end of his sentence. By the end of the year he emerged from battle wounded, after having engaged in fierce fighting in Ukraine. ${ }^{11}$

Ten San Din saw the start of the war in Kzyl-Orda, in south central Kazakhstan. ${ }^{12}$ His family had been among the first group of Soviet Koreans

7 Maslov Ivan Vladimirovich, http://iremember.ru/memoirs/tankisti/maslov-ivan-vladimi rovich/.

8 On this occupation see, for example, N. I. Egorova, "Iranskii krizis" 1945 - 1946 gg. Po rassekrechennym arkhivnym dokumentam, in: Novaia i noveishaia istoriia 3. 1994, pp. 24-42; Jamil Hasanli, The Soviet-American Crisis over Iranian Azerbaijan, 1941 - 1946, Landham 2006.

9 Krasil'shchikov-Golodets Iakov Solomonovich, http://iremember.ru/memoirs/pekhotintsi/ krasilschikov-golodets-yakov-solomonovich/.

10 On the Gulag at war see Edwin Bacon, The Gulag at War. Stalin's Forced Labor System in the Light of the Archives, New York 1994; Fyodor Vasilevich Mochulsky, Gulag Boss. A Soviet Memoir, Oxford 2012.

11 On the drafting of Gulag inmates and special settlers into the Red Army see Glantz, Colossus Reborn, pp. 544-547; V. N. Zemskov, Sud'ba "kulatskoi ssylki" (1930-1954 gg.), in: Otechestvennaia istoriia 1. 1994, pp. $118-147$, here pp. $130 \mathrm{f}$.

12 Ten San Din, http://iremember.ru/memoirs/razvedchiki/ten-san-din/. 
deported from the Far East in 1937, as the Soviet administration prepared for war with Japan by systematically clearing the borders of national minorities who might find common cause with the enemy in the event of war. More than 172,000 Koreans were victims of this campaign, which was the first deportation of an entire ethnic group in Soviet history. ${ }^{13}$ In October 1938, Ten San Din's father was shot during Stalinist repressions - but not before instilling in his son a sense of duty to liberate Korean people from the Japanese threat. Thus, when the war broke out, Ten San Din immediately volunteered for the Soviet army, eager to fight. As the son of an "enemy of the Soviet people," however, he was only drafted after making seven formal requests. Like Sidorov, Ten San Din joined the war following an announcement by Molotov - though not on 22 June when Germany had attacked, but rather on August 9, 1945 when the war against Japan was announced. Ten San Din served in the Pacific Fleet during the 24 days of war with Japan; although he was a late entrant into the theater of war, he continued to actively protect Soviet interests until 1957 as Moscow's representative in North Korea. ${ }^{14}$

As a historical source, iremember.ru can perhaps be best described as painting a cubist image of the Soviet Second World War. The collected stories combine multiple viewpoints across an array of different beginnings and endings in both time and space. It is a source that is both demanding and rewarding for those who seek to engage with it. Taken as a whole, it can be overwhelming and confusing. Used carefully, it provides unique insight into the Soviet wartime experience. In moving from Moscow to Big Diomede, or from the heart of Kazakhstan to Tehran, and from the 1930s into and even beyond the 1950s, the numerous interviews stretch the conventional timeframe and geographical focus of the war. It is also a source replete with all manner of different voices, from the heroes of the Soviet Union - including individuals like test pilot Stepan Mikoyan, son of one of Stalin's closest comrades, Anastas Mikoyan - to former camp inmates; from devoted Communists to the ideologically uncertain, and everything in between. Since first coming online in 2000, the iremember.ru database has grown rapidly. Currently it contains some 2,500 interviews, with more being added regularly. ${ }^{15}$

13 Mark Edele, The Second World War as a History of Displacement. The Soviet Case, in: History Australia 12. 2015, no. 2, pp. $17-40$, here esp. p. 23; T. V. Tsarevskaya-Dyakina (ed.), Istoriia Stalinskogo Gulaga. Konets 1920-ikh - pervaia polovina 1950-ikh godov. Sobranie dokumentov v semi tomakh, vol. 5: Spetspereselentsy v SSSR, Moscow 2004, p. 237. More would follow: Terry Martin, The Origins of Soviet Ethnic Cleansing, in: The Journal of Modern History 70. 1998, pp. 813-861; N. L. Pobol' and P. M. Polian (eds.), Stalinskie deportatsii 1928-1953, Moscow 2005.

14 On the Soviet campaign against Japan see V. N. Bartanov et al., Sovetsko-iaponskaia voina 1945 goda: istoriia voenno-politicheskogo protivoborstva dvukh derzhav v 30 - 40e gody, Moscow 1997; David M. Glantz, Soviet Operational and Tactical Combat in Manchuria, 1945. “August Storm,” New York 2003.

15 Number as of March 2016. 
To date the database has predominantly been the focus of targeted research by historians who have used specific interviews to complement other sources. Selected interviews have, for example, featured in explorations of attitudes towards the war within army ranks, the wartime experiences of women and Jewish soldiers, and in a study on Soviet defectors. ${ }^{16}$ The database has also been used for writings on the movement of people across Soviet territories, the civilian experience of German occupation, and new military histories of this war. ${ }^{17}$ Each of these studies has considered a relatively small selection of interviews, from as few as one to a maximum of about thirty. Yet while the source is gradually forcing its way into history scholarship, within the field of memory studies iremember.ru has received limited attention. ${ }^{18}$ As an oral history project iremember.ru provides an opening for a series of questions around the issue of production and consumption of memory in Russia. Furthermore, approaching this source through a theoretical framework offered by scholars who have probed the tension between national and social (collective) memory extends efforts to build a political vocabulary for describing Russia today. ${ }^{19}$

In this essay we argue that the iremember.ru website posits intriguing questions for the study of the politics of history in Putin's Russia. We demonstrate that the content of the database provides anything but the polished mythological narrative usually associated with the return of the myth of the Great Patriotic War as a central pillar of national consciousness. Rather, the Russian state has begun to support what originally was a grassroots

16 Reese, Why Stalin's Soldiers Fought; Oleg Budnitskii, The Great Patriotic War and Soviet Society. Defeatism, 1941 - 42, in: Kritika. Explorations in Russian and Eurasian History 15. 2014, pp. 767-797; Alexander Hill, Voroshilov's "Lightning" War. The Soviet Invasion of Poland, September 1939, in: The Journal of Slavic Military Studies 27. 2014, pp. 404-419; Roger D. Markwick and Euridice C. Cardona, Soviet Women on the Frontline in the Second World War, London 2012; Kiril Feferman, “The Jews' War." Attitudes of Soviet Jewish Soldiers and Officers toward the USSR in 1940-41, in: The Journal of Slavic Military Studies 27. 2014, pp. 574 - 590; Mark Edele, Stalin's Defectors. How Red Army Soldiers Became Hitler's Collaborators, 1941 - 1945, Oxford 2017.

17 Moch and Siegelbaum, Broad Is My Native Land; Mordechai Altshuler, Evacuation and Escape during the Course of the Soviet-German War, in: Dapim. Studies of the Holocaust 28. 2014, no. 2, pp. 57-73; Alexander Hill, The Red Army and the Second World War, Cambridge 2017; Johannes Due Enstad, Soviet Russians under Nazi Occupation. Fragile Loyalties in World War II, Cambridge 2018.

18 Seth Bernstein, Remembering War, Remaining Soviet. Digital Commemoration of World War II in Putin's Russia, in: Memory Studies 9. 2016, pp. 422-436, here pp. 427-429; Stephen M. Norris, Memory for Sale. Victory Day 2010 and Russian Remembrance, in: The Soviet and Post-Soviet Review 38. 2011, pp. $201-229$, here p. 221; Irina Rebrova, Oral History im heutigen Russland. Tätigkeitsfeld, Probleme und Perspektiven, in: BIOS 22. 2009, pp. 293 -300, here pp. 297 f.

19 Svetlana Boym, From the Russian Soul to Post-Communist Nostalgia, in: Representations 49. 1995, pp. 133 - 166; id., The Future of Nostalgia, New York 2001; Ellen Rutten et al. (eds.), Memory, Conflict and New Media. Web Wars in Post-Socialist States, Abingdon 2013. We use "social" and "collective" memory as synonyms. 
initiative documenting social memory in all its messiness. This embrace of the project by the Russian state puts into doubt arguments about a single masternarrative about the Second World War in Putin's Russia. Bringing together history, memory studies, and political science, we argue that the memory of this war is "managed" rather than "controlled," which mirrors dynamics in the wider system of symbolic politics.

\section{The Background and Structure of the iremember.ru Collection}

The iremember.ru website began as a small collection of interviews that founder Artem Drabkin, a biologist (kandidat biologicheskikh nauk) by training and war history enthusiast by calling, had conducted with Soviet and German war veterans in the late 1990 s. $^{20}$ In establishing the website, Drabkin's aim, as he has explained several times in media interviews, was to add an experiential dimension to our knowledge of the Second World War, by breaking away from the focus on the events of the war and restoring an emotional element to the wartime narrative. Such an emotional element had long been absent from the Russian discourse on the war, which was dominated by what Drabkin referred to as "polished" (glatkie) personal accounts from published memoirs that fit neatly within the grand narrative offered in history books. This mission was triggered by Drabkin's interest in war history and the veterans in his own family, as well as his own experience of war in Georgia where he was accompanying a British news crew covering the conflict in this former Soviet republic during the 1990s. Drabkin's own emotional response to this event inspired a desire to learn more about how those who had experienced the Second World War had perceived and dealt with the extremes that they had faced. He determined that oral history was particularly suited to this project, as face-to-face interviews offered the unique opportunity for a larger swath of the population to give their account of history. The timing of Drabkin's project was fortuitous, as self-censorship within Russian society seemed to have receded substantially in the 1990s, and conversations that would usually have been confined to the kitchen table were gradually becoming part of public discourse. Many veterans also felt liberated by their twilight years and were more comfortable to speak about the events that had defined the earlier stages of their lives.

Drabkin's project anticipated a widespread need for this type of historical account. In his study "Memory of a Brutal Regime," Nikolai Koposov drew upon the results from opinion polls conducted in 1990 and 2007 to investigate

20 Interview with Artem Drabkin on the program Razvedopros, 22.1.2015, https://www. youtube.com/watch?v=buqkf5kZ_rI. See also his interview on the program Ledokol mnenii on Stolitsa 99.6 FM, 16.4.2015, https://www.youtube.com/watch?v=sVEn3zllP7Y. 
the source materials used by Russians to learn about their national history. While the 1990 poll revealed that most people obtained information about the past through literature and film, in 2007 teaching at educational institutions had taken over as the primary source of knowledge. Interestingly, both polls showed that only very small number of respondents learned about the past through recollections of their family members and relatives. ${ }^{21}$ The need to include familial accounts within the official narrative about the country's past was recognized during the 2000s and 2010s, as the government made concerted efforts to create sources of popular solidarity. This recognition was voiced, for example, in the report on the question of "National Identity and the Future of Russia" published by Kremlin-endorsed think tank the Valdai Discussion Club in 2014, which highlighted that in order to support the "patriotic education" of future generations, "the history of the country as a whole can and must be made personal." 22 Drabkin's collection thus gave life to an area within the Russian mnemonic landscape that had previously remained underexplored, and for which there was a growing appetite.

In 2001 - just one year after the first iteration of Drabkin's project appeared online - iremember.ru received support from the Russian Federal Agency for Press and Mass Communications. The funding allowed Drabkin to employ a team of co-workers and begin developing the website into what has become the largest collection of its type. Materials published on the website are classified into one of three sections: "Veterans of the Great Patriotic War" (veterany VOV); "Allies and Enemies" (soiuzniki i protivniki) and "Contemporaries" (sovremenniki). The "Veterans" section is the largest. Transcribed interviews, which constitute the main body of the collection, are complemented with audio recordings, letters sent by soldiers from the front and additional miscellaneous materials, from a piece on Australian pilots who fought in the Second World War, to excerpts from the diary of a German soldier from 1942 and Drabkin's newspaper articles on the Soviet wartime experience. Drabkin acknowledges that this collection, like any historical source, has its blind spots. He insists that it should be used in concert with archival material, published memoirs and existing scholarship. The interviewees all belong to a particular generation, namely those who were between 17 and 22 years of age when the war began; ${ }^{23}$ they are also the people who agreed to be interviewed, and who felt that their actions during the war had been correct. Drabkin admits that certain groups are not represented in the database, especially members of national minorities, and that as such the source does not reflect the Soviet

21 Nikolai Koposov, Pamiat' strogogo rezhima. Istoriia i politika v Rossii, Moscow 2011, pp. $181-183$.

22 Valdai Discussion Club, National Identity and the Future of Russia, Moscow 2014, http:// vid-1.rian.ru/ig/valdai/Identity_eng.pdf, p. 44.

23 The Soviet draft cohorts of 1941 - 1945 were indeed much more extensive, covering men born between 1890 and 1927. See Mark Edele, Soviet Veterans of the Second World War. A Popular Movement in an Authoritarian Society, 1941 - 1991, Oxford 2008, pp. 13 - 15. 
people as a whole. Insofar as national minorities (natsmen) are represented, they are generally those who were integrated into the Soviet system. This is well illustrated in the interview with Ten San Din, whose family was deported, and whose father was shot in 1938, but who was eager to serve in the Soviet army and later fight for Soviet interests in North Korea for a number of years. Ten San Din concludes his interview with a statement that Russian and Soviet literature and culture would always remain his (intellectual) homeland. An exception to the under-representation of minorities are Jews, who have a fairly high profile, thanks to Grigorii Koifman, who conducted about 200 interviews in Israel. Also represented are Crimean Tatars and Kalmyks. ${ }^{24}$

Despite its inherent restrictions, the material assembled within the database is striking in its diversity. ${ }^{25}$ In most instances an entry consists of a transcribed interview conducted by one of the project members with a veteran of the Second World War. Many interviews follow a formal structure, with each question being followed by an answer; in other examples the narrative might run continuously, such that the interviewer's questions can only be discerned indirectly. Scholars who have worked with the source have suggested that the interviews were and are being conducted using a common methodological framework, with a questionnaire designed specifically for the project. ${ }^{26}$ On the question of interview post-production, Drabkin has explained that interview transcripts are not subjected to any kind of censorship and are only edited to the extent that the spoken language of the interview can flow better in a written form. ${ }^{27}$ The most relevant interventions in the text are explanations of certain terms added by editors that clarify the frontline language, noting that "horseless tank crew members" (bezloshadnye tankisty) were those without a tank; that a "samovar" (or chainik) is a soldier who had lost all of his limbs; that a "coffin with music" (grob s muzykoi) refers to a tank; that a "tongue" (iazyk) is an enemy soldier captured with the aim of extracting information from him; and that a "buyer" (pokupatel') is a person selecting from soldiers in the reserve to complete his unit or regiment.

24 Artem Drabkin in Ledokol mnenii on Stolitsa 99.6 FM, 16.4.2015, https://www.youtube. $\mathrm{com} /$ watch $\mathrm{v}=\mathrm{sVEn} 3 \mathrm{zllP7Y}$.

25 The assessment of the source in this article is based on the examination of approximately 470 interviews in the collection. This sample included the entire infantry section (which numbers around 250 infantry) as well as the tank crew and the NKVD/SMERSH sections (around 90 and 30 interviews respectively) which allowed for a combination of memoirs from the most common rank and file to elite military groups. In addition, 100 interviews were selected at random from other groups.

26 The questionnaire is not available on the website at the time of writing. It is mentioned in Roger R. Reese, Motivations to Serve. The Soviet Soldier in the Second World War, in: The Journal of Slavic Military Studies 20. 2007, pp. 263-282, here p. 270; id., Why Stalin's Soldiers Fought, p. 319; Bernstein, Remembering War, Remaining Soviet, pp. $427 \mathrm{f}$.

27 See Drabkin in Ledokol mnenii and Maksim Timonov, Otsifrovka pamiati, in: Itogi, 3.5.2010, http://www.itogi.ru/obsh-tema/2010/18/151638.html. 
In addition to the transcript of the interview, the entries often contain other types of egodocuments. The entry on pilot Ivan Luk'ianov (letchik istrebitel'), for example, consists of a combination of his memoirs (published in 2008 under the title "Razmyshleniia Ivana Petrovicha Luk'ianova") and an interview. ${ }^{28}$ The memoirs section covers the family history of working on Count Tolstoy's estate in Iasnaia Poliana, as well as his childhood memories, recollections of when the Revolution arrived in the village, the introduction of the New Economic Policy and the associated effect on everyday life, the effect of repressions, Luk'ianov's first efforts in aviation, his training and ultimately his wartime service. This material is divided into chapters and followed by a set of questions from the interviewer concerning certain specific aspects of Luk'ianov's service. There are numerous examples of memoirs that have been donated to the website by veterans' family members. For example, Valentin Bakaev's recollections, which were transcribed by his son Aleksei while Valentin was in hospital in February 1987, have recently been donated to the website; similarly, (minometchik) Artem Dzhesmedzhiian's wartime memoirs were lying unread in a desk drawer until his grandson sent them to iremember.ru and gave the website exclusive publication rights. ${ }^{29}$ The interviews often include documentation pertaining to military awards received by the veterans. Wherever possible any such award documentation is crossreferenced with information on Podvig naroda - an electronic database of documents from the Central and Naval Archives of the Russian Ministry of Defense pertaining to Second World War military decorations. ${ }^{30}$

Many of the entries have a unique structure that departs from the conventional interview format. The recollections of tank crew member Iakov Kovalenko, for example, begin with his memories of the war, before giving way to a description of a collection of his poems concerning his wartime experience, as well as the life of veterans in the years following the war and up to late 1990s and early 2000s. ${ }^{31}$ Furthermore, despite the common belief that maintaining a diary during the war was strictly prohibited, several entries contain wartime diaries, such as those of doctor Iakov Polonskii, which cover his experience working in Leningrad and on the island of Lavan in the Gulf of Finland during 1942 and $1943 .^{32}$

28 Luk'ianov Ivan Petrovich, http://iremember.ru/memoirs/letchiki-istrebiteli/lukyanovivan-petrovich/.

29 Bakaev Velentin Nikiforovich, http://iremember.ru/memoirs/pekhotintsi/bakaev-valen tin-nikiforovich/; Dzhesmedzhiian Artem Arshakovich, http://iremember.ru/memoirs/ minometchiki/dzhesmedzhiyan-art-m-arshakovich/.

30 Elektronnyi bank dokumentov "Podvig naroda $\mathrm{v}$ velikoi otechestvennoi voine 1941 - 1945 gg," http://podvignaroda.mil.ru/?\#tab=navHome.

31 Kovalenko Iakov Iakovlevich, http://iremember.ru/memoirs/tankisti/kovalenko-yakovyakovlevich/. This material was donated to the website in 2015.

32 Polonskii Iakov Natanovich, http://iremember.ru/memoirs/mediki/polonskiy-yakovnatanovich/. 
Within online spaces, as Ellen Rutten and Vera Zvereva note in their study on post-socialist digital memories, "knowledge and memory are rarely stored in the form of a final text." ${ }^{\text {"3 }}$ Indeed, the iremember.ru collection presents information in fragments and does not claim to offer its readers a comprehensive or complete account of wartime events. As such, it falls within the category of what Svetlana Boym has defined as social memory. In her seminal study of nostalgia and post-communist memory, Boym distinguished between national memory, which tends to be based on a single version of national identity, and social memory, which is polyphonic and fragmented, and exists across a series of collective frameworks. While national and social memory might overlap in their frames of reference, they do not coincide in their narrative or plots of identity. ${ }^{34}$ Notably, Boym argued that histories that countered official narratives were in Soviet times the basis for democratic opposition to the ruling regime. Historians working on memory in postsocialist spaces, however, have observed that there was no neat divide between official memory and dissenting or counter memory - or, as Boym would categorize it, between national and social memory. ${ }^{35}$ The evolution of the iremember.ru database, as an artefact of social memory which has become integrated within national memory, provides important insight into the conditions that make this absorption possible.

\section{The Memory Networks}

As an oral history collection dedicated to the Soviet wartime experience, iremember.ru engages with a mnemonic trope that has been central to the evolution of official ideology in both the Soviet Union and in post-Soviet Russia. Unlike the October Revolution and subsequent Civil War, which created deep political and ideological divides within society, victory over a foreign enemy in the Second World War had a unifying effect on the country. In turn, as a major source of popular solidarity, the (idealized) memory of the war evolved into an effective founding myth. Indeed, while this myth has undergone a series of transformations over time, its currency has always remained strong. ${ }^{36}$ Even as the official ideology eroded rapidly during the

33 Ellen Rutten and Vera Zvereva, Introduction. Old Conflicts, New Media. Post-Social Digital Memories, in: Rutten, Memory, Conflict and New Media, pp. 24-61, here p. 37.

34 Boym, The Future of Nostalgia; id., From the Russian Soul to Post-Communist Nostalgia.

35 Julie Fedor, Conclusion, in: Rutten, Memory, Conflict and New Media, pp. 499-519, here p. 507.

36 Norris, Memory for Sale, pp. 203-215; id., Blockbuster History in the New Russia. Movies, Memory and Patriotism, Bloomington 2012; Mark Edele, Fighting Russia's History Wars. Vladimir Putin and the Codification of World War II, in: History \& Memory 29. 2017, pp. 90 - 124, here pp. 97 f.; most recently: Philipp Bürger, Geschichte 
twilight years of the Soviet Union, the war, as historian Nina Tumarkin would observe in 1987, remained "the most effective cluster of political rituals and political symbols operating in the Soviet Union today." 37 Perceptions of the war would, however, begin to shift with the onset of glasnost and perestroika, as more open debate over dark and traumatic episodes of Soviet history became possible. In particular, information pertaining to insufficient preparations, disorganization during conflict, enormous losses of human life, the brutal treatment of soldiers by their superiors, and the behavior of Red Army soldiers in liberated territories exposed the ugly face of the war, ${ }^{38}$ and prompted commentators, including Tumarkin, to declare the "swan song of the cult of the Great Patriotic War." 39

This declaration would prove premature, as the rise of Vladimir Putin saw the myth of the Second World War revived on a grand scale. ${ }^{40}$ Historians have observed that the evolution of Putin's regime over the past two decades has been accompanied by a new revision of Russian history and the (re) emergence of "the national patriotic school of Russian historiography" that promotes a positive account of the nation's past. ${ }^{41}$ This patriotic history serves to enforce the narrative of Russia as a proud and powerful nation, a narrative that has filled the ideological vacuum created by the dissolution of the Soviet Union. ${ }^{42}$ Within this narrative, the great achievements of the Russian Empire are placed in a continuum with the military victories of the Soviet Union, while less glorious episodes are either relativized or marginalized. In parallel, critics of this selective approach to history have been marked as "blackeners" who threaten national cohesion. This "battle for history," as historian Nikolai Koposov has termed it, ultimately frames the regime's domestic and foreign

im Dienst für das Vaterland. Traditionen und Ziele der russländischen Geschichtspolitik seit 2000, Göttingen 2018.

37 Nina Tumarkin, Myth and Memory in Soviet Society, in: Culture and Society 24. 1987, no. 6 , pp. $69-72$, here p. 69.

38 Robert W. Davies, Soviet History in the Gorbachev Revolution, London 1989; id., Soviet History in the Yeltsin Era, New York 1997.

39 Nina Tumarkin, The Living and the Dead. The Rise and Fall of the Cult of World War II in Russia, New York 1994, p. 200.

40 Gregory Carleton, Russia. The Story of War, Cambridge, MA 2017; Shaun Walker, The Long Hangover. Putin's New Russia and the Ghosts of the Past, Oxford 2018.

41 Teddy J. Uldricks, War, Politics and Memory. Russian Historians Reevaluate the Origins of World War II, in: History \& Memory 21. 2009, no. 2, pp. 60 -82, here p. 68. See also Koposov, Pamiat' strogogo rezhima; Dina Khapaeva, Historical Memory in Post-Soviet Gothic Society, in: Social Research 76. 2009, pp. 359-394; id., Triumphant Memory of the Perpetrators. Putin's Politics of Re-Stalinization, in: Communist and Post-Communist Studies 49. 2016, pp. 61 - 73; Edele, Fighting Russia's History Wars.

42 On the attempts to define a new Russian idea during the presidency of Boris Yeltsin see Milan Subotić, "Druga Rusija." Uvodne napomene, in: Milan Subotić (ed.), Druga Rusija. Kritička misao u savremenoj Rusiji, Belgrade 2015, pp. 5-38, here p. 24; Masha Gessen, The Future Is History. How Totalitarianism Reclaimed Russia, London 2017, pp. $174 \mathrm{f}$. 
policy. ${ }^{43}$ Internally, creating a positive account of national history and casting the President in the role of its guardian has been part of an effort to define a source of popular solidarity and consensus between the state and society. ${ }^{44}$ This consensus would play a major role in attempts to immunize Russia against a potential "color revolution," most acutely during the protest season of $2011-2013 .^{45}$ At an international level, maintaining a positive myth of the Second World War has become especially critical in the face of rising nationalist (and revisionist) historiography in the other successor states of the Soviet Union, whose hostility to the communist past and reassessments of wartime history threatened to undermine the Soviet defeat of Nazism - an achievement that was at the heart of the Soviet Union's claim to the status of a superpower, and which Russia, as its formal heir, continues to draw upon. ${ }^{46}$

Russia's official Second World War narrative is supported by a developed memory infrastructure, which includes the production of new history textbooks, memory laws, public commemorations, monuments, television programs and films. ${ }^{47}$ Since the early 2000 s, and particularly in the period leading up to the seventieth anniversary of Victory Day in 2015, official efforts to integrate the Internet into this infrastructure saw the launch of a series of online projects dedicated to the history and memory of the Second World War. Podvig naroda, for example, hosts an electronic database of documents from the Central and Naval Archives of the Russian Ministry of Defense pertaining to Second World War military decorations awarded to Soviet soldiers, established by the Ministry of Defense of the Russian Federation. ${ }^{48}$ Pobeda

43 See Nikolai Koposov, The Armored Train of Memory. The Politics of History in PostSoviet Russia, in: Perspectives on History 49. 2011, no. 1, https://www.historians.org/ publications-and-directories/perspectives-on-history/january-2011/the-armored-trainof-memory-the-politics-of-history-in-post-soviet-russia.

44 On Putin's personal connection to the history of the Second World War see, for example, Elizabeth Wood, Performing Memory. Vladimir Putin and the Celebration of World War II in Russia, in: The Soviet and Post-Soviet Review 38. 2011, pp. 172-200; Vladimir Putin prinial uchastie v aktsii "Bessmertnyi polk," in: kremlin.ru, 9.5.2017, http:// kremlin.ru/events/president/news/54473.

45 See Robert Horvath, Putin's "Preventative Counter-Revolution." Post-Soviet Authoritarianism and the Spectre of Velvet Revolution, in: Europe-Asia Studies 63. 2011, pp. 1 -25; id., Putin's Preventive Counter-Revolution. Post-Soviet Authoritarianism and the Spectre of Velvet Revolution, London 2013.

46 See, for example, Karsten Brüggemann, Russia and the Baltic Countries Recent RussianLanguage Literature, in: Kritika. Explorations in Russian and Eurasian History 10. 2009, pp. 935-956; Andreas Umland, Bad History Doesn't Make Friends, in: Foreign Policy, 25.10.2016, http://foreignpolicy.com/2016/10/25/bad-history-doesnt-make-friendskiev-ukraine-stepan-bandera/.

47 See Nikolai Koposov, Memorial'nyi zakon i istoricheskaia politika v sovremennoi Rossii, in: Ab Imperio 2. 2010, pp. 249-274.

48 Elektronnyi bank dokumentov "Podvig naroda v velikoi otechestvennoi voine 1941 - 1945 gg," http://podvignaroda.mil.ru/?\#tab=navHome. 
1941-1945, created by the Federal Archival Agency as part of an official project dedicated to the patriotic education of citizens of the Russian Federation, contains a large collection of photo-documentation of the Second World War. ${ }^{49}$ The databases Memorial and Pamiat' naroda (1941 - 1945), both developed by the Ministry of Defense, contain archival documents pertaining to the Red Army. ${ }^{50}$ The state-sponsored television channel RT has launched its own online project entitled War Witness: Heritage, which includes around 100 short video interviews with war veterans. ${ }^{51}$

Alongside these official efforts, the number of small, grassroots online projects associated with the war has grown rapidly, including Kalendar' Pobedy, which is dedicated to key events of the Great Patriotic War; Geroi strany, which contains biographies of those who received the highest Soviet Union distinction, "Hero of the Soviet Union"; Pobediteli 1941-1945, which lists the names of Soviet war veterans in Russia and abroad; and WarSpot, which covers various historical and contemporary conflicts. ${ }^{52}$ Within this space, Drabkin's iremember.ru database occupies a unique position: while it initially emerged as one of these grassroots initiatives dedicated to preserving the memory of the war, it was subsequently co-opted into the official online memory network. How, then, does a project that emerged out of a desire to go beyond the "polished" accounts of the Second World War function as part of the official memory landscape, which is defined by its positive approach to history, and moreover uses instruments such as the memory law to limit the extent to which certain aspects of the war can be explored?

\section{The Messiness of Social Memory}

There is nothing polished about iremember.ru accounts. Consider the recollections of our five introductory soldiers: Zlatkin does not shy away from discussing the brutal treatment of soldiers by army commanders, the disorder within the ranks during the initial months of the war, or his experience of the Soviet filtration process after returning from behind enemy lines. Sidorov's recollection of the war begins on September 17, 1939 with the Red Army's Polish campaign, officially an effort to "liberate ancient Soviet

49 Pobeda 1941 - 1945, O saite, http://victory.rusarchives.ru/o-sayte.

50 Memorial, https://obd-memorial.ru/html/about.htm; Pamiat' naroda (1941-1945), https://pamyat-naroda.ru.

51 War Witness: Heritage, http://catalog.rt.com/en/series/war-witness-heritage/. On War Witness: Heritage see Jussi Lassila, Witnessing War, Globalizing Victory. Representations of the Second World War on the Website Russia Today, in: Rutten, Memory, Conflict and New Media, pp. $448-474$.

52 Kalendar' Pobedy 1943 - 1945, http://pobeda.elar.ru/about/; Geroi strany, http://www. warheroes.ru/about.asp; WarSpot, https://warspot.ru/pages/about; Pobediteli 1941 - 1945, https://www.pobediteli.ru/about.html. 
lands of Western Ukraine and Belorussia." He recalls observing the joint work of the Soviet-German official commission to establish a new border under the slogan "Stalin and Hitler - peace and friendship." Maslov's account similarly begins in the Western territories during the formation of the new border, and includes episodes of local hostility toward the Soviet army. Krasil'shchikovGolodets's interview is dominated by his memories of the Great Purge - the arrest of his mother in 1937 as an "enemy of the people," the arrest and execution of her brothers, his step-father's fear he would be taken away at any point and the heavy atmosphere of his communal apartment where indeed everyone was "waiting their turn" to hear that knock at the door in the middle of the night. His experience of serving in the war was marked both by the fact he was the son of an "enemy of the people" and a former Gulag prisoner (zek), having served three years in the camps prior to being sent to the front in 1943. The story of Ten Sen Din, another son of an enemy, similarly opens with his recollections of Stalinist deportations and the Great Terror.

These five accounts are hardly unique. Those who explore the iremember.ru database will find that a large number of interviews begin with questions about memories of the 1930s, with an emphasis on collectivization and the Great Terror. The history of political repression in the Soviet Union generally remains on the margins of the official historical discourse (although this does not suggest collective amnesia about this traumatic past). ${ }^{53}$ Public commemoration of this history is limited and predominantly organized through private initiatives and NGOs such as the Memorial Society, rather than by the state. ${ }^{54}$ Here, however, the history of Stalinist terror is integrated within these accounts of the Second World War; furthermore, these accounts often openly confront difficult wartime memories.

The question of military discipline, for example, frequently emerges: veterans variously recall their reaction to the presence of NKVD or SMERSH officers in their units, the infamous Order No. 227 ("Not one step back!"), the existence of the penal battalions, or the exemplary execution of Soviet soldiers. Accounts of exemplary shootings (pokazatel'nye rasstrely) in particular make for disturbing reading and interviewees frequently express bitterness toward such

53 See Alexander Etkind, Post-Soviet Hauntology. Cultural Memory of the Soviet Terror, in: Constellations 16. 2009, pp. 182-200, here p. 193. On Putin's commemoration of Stalinist terror see Mark Edele, Is the Russian Revolution over Yet?, in: Pursuit, 8.11.2017, https://pursuit.unimelb.edu.au/articles/is-the-russian-revolution-over-yet.

54 Memorial Society, https://www.memo.ru/ru-ru/. An exception was the unveiling of the "Wall of Sorrow" by President Putin in October 2017. See Opening of Wall of Sorrow Memorial to Victims of Political Repression, in: kremlin.ru, 30.10.2017, http://en. kremlin.ru/events/president/news/55948. Online initiatives commemorating this history are either private enterprises or projects developed by academic institutions abroad such as, for example: George Mason University, Gulag. Many Days Many Lives, http:// gulaghistory.org; University of Toronto, Project for the Study of Dissidence and Samizdat, https://samizdatcollections.library.utoronto.ca. 
draconian measures. Tank crew member Vasilii Briukhov recounts the story of tank commander lieutenant Ivanov, a Communist in his early thirties whose wife and two children were brutally murdered in Romania. Upon learning of their destiny once the Soviet army crossed into Romania, Ivanov, as Briukhov recalls, entered the combat arena fixated on revenge. At one point, and in an alcoholic stupor, he and a tank driver set out to harass a local Romanian family. After a failed attempt to rape one of the women, Ivanov shot her dead. He was sentenced to death by the NVKD and faced the firing squad, an outcome that left his comrades in arms with feelings of great contempt for their superiors. $^{55}$

Elsewhere, the drinking culture within the army emerges as a category in its own right. Alcohol serves as a nexus between several frontline themes, from the psychological state of soldiers and wartime medicine - for which alcohol served as a "frontline anesthetic" when other supplies were short - to the function of alcohol as a driver of human ingenuity and a trophy object across military fronts during the war (from German brandy and wine, or Russian vodka on the German front, to Japanese sake in Mongolia and China). ${ }^{56}$ Alcohol also features as cause of numerous inglorious deaths and tactical failures, and plays a central role in some of the most disturbing and horrific images that emerge from the interviews. Infantryman Valentin Bakaev remembers an incident in Nikopol in Ukraine, which took place following the expulsion of the German army from this territory in 1944. His group of about twenty men entered the brewery (pivzavod) to witness a simultaneously terrible and ridiculous scene: the entire yard was covered with soldiers, some sleeping, others crawling on all fours. The commander immediately realized that twenty men would not be enough to deal with the situation at the brewery, and that it would take them an entire day to disarm and relocate these men, most of whom were either soldiers who had fallen behind their units or gang members (shatiia bratiia) on a trophy hunt. It was when they entered the cellar that the full scale of this mayhem was revealed: the space was flooded with beer, and soldiers and their officers were swimming in it. They would remove 21 people from this "beer bath" (pivnaia vanna), five of whom were dead. A fellow veteran, Mikhail Levin, describes the massacre on the river Molochnaia near Melitopol' in Ukraine when, believing that they had driven the German army away, Soviet soldiers descended upon a local distillery (spirtzavod). Two hours later, German soldiers returned. By now, few of the intoxicated Soviets could stand firmly on their feet and return fire. Those who were able to retreat left behind a horrid scene - ten days later, when they were able to push the

55 Briukhov Vasilii Pavlovich, http://iremember.ru/memoirs/tankisti/briukhov-vasiliypavlovich/.

56 Demchenkov Viktor Semenovich, http://iremember.ru/memoirs/artilleristi/demchenkovviktor-semenovich/. 
Germans back and return to the distillery to bury their fellow soldiers, 500 men were laid to rest in a common grave. ${ }^{57}$

Another charged topic is the so-called "question of nationalities" (natsional'nyi vopros), which relates to the relationships between Soviet soldiers of various ethnic and religious backgrounds during the war. ${ }^{58} \mathrm{~A}$ significant number of these interviews include accounts of the Jewish experience of serving in the Soviet army, ${ }^{59}$ and some familiar themes emerge - including accusations that Jews spent the war far from the frontline in Tashkent or Birobidzhan (which appear to have been widespread among the Soviet population at the time), and efforts by Jewish soldiers fighting in the Soviet army to rebut the clichéd label of "Jews as cowards" (evrei-trus). ${ }^{60}$ These stories also provide insight into the need to maintain a fluid identity during the war, with the phenomenon of "hidden Jews" - soldiers who decided to "enroll in the great brotherly family of Slavonic peoples" by falsifying their names and nationality frequently raised. Viktor Granovskii, for example, was fortunate to find a sympathetic captain who registered his nationality as Belarusian instead of Jewish, and his patronymic as Mikhailovich instead of Moiseevich. ${ }^{61}$ He was fortunate because, as he claims, a Jew was as likely to be shot in the back by a comrade as he was to die from an enemy bullet. Others maintained their Jewish identity on their papers, but concealed this identity in everyday life; Aaron Kande, for example, used his birth name on his passport, but was known as Iura among his friends. ${ }^{62}$ Antisemitism was not necessarily the sole impetus for a Jewish soldier to refashion his own identity: Aleksandr Aronas sought to conceal not only his Jewish identity, but also the fact that he came from a family of special settlers, and that he had spent part of the war in German-occupied territory, all of which could have landed him in trouble. ${ }^{63}$

57 Levin Mikhail Borisovich, http://iremember.ru/memoirs/pekhotintsi/levin-mikhailborisovich/.

58 On this issue see Brandon Schechter, "The People's Instructions." Indigenizing the Great Patriotic War among "Non-Russians," in: Ab Imperio 3. 2012, pp. 109-133; Mark Edele, The New Soviet Man as a "Gypsy." Nomadism, War, and Marginality in Stalin's Time, in: REGION. Regional Studies of Russia, Eastern Europe, and Central Asia 3. 2014, pp. 285 -307; Moritz Florin, Becoming Soviet through War. The Kyrgyz and the Great Fatherland War, in: Kritika. Explorations in Russian and Eurasian History 17. 2016, pp. $495-516$.

59 See Itzhak Arad, In the Shadow of the Red Banner. Soviet Jews in the War against Nazi Germany, Jerusalem 2010.

60 See for example the interview with Ion Lazarevich Degen, http://iremember.ru/ memoirs/tankisti/degen-ion-lazarevich/.

61 Granovskii Viktor Moiseevich, https://iremember.ru/memoirs/pekhotintsi/granovskiyviktor-moiseevich/.

62 Kande Aaron Isaevich, https://iremember.ru/memoirs/minometchiki/kande-aaronisaevich/.

63 Aleksandr Mikhailovich Aronas, https://iremember.ru/memoirs/tankisti/aronas-aleksandrmikhaylovich/. 
The complex phenomenon of antisemitism within the ranks of the Soviet army is further illustrated by the use of the "our Jew" (nash evrei) epithet, which is described in several interviews as a term used for Jewish soldiers by their comrades on the frontline to make a distinction between Jews serving on the frontline and those sitting in the rear. Jewish soldiers do not, however, seem to perceive this appellation as discriminatory. Isaak Uritskii, for example, notes that his fellow tank crew members often told him "Sashka, you're not a Jew, you're brave, you're one of us, a Russian," before explaining to his interviewer that, as a result, he "didn't feel particular antisemitism on the front." ${ }^{64}$ Jewish veterans frequently remark that antisemitism on the frontline was either absent, or perhaps less significant than elsewhere. Hospitals, for example, often appear in these accounts as spaces where the myth of a brotherhood of nations is put to rest, as Jewish soldiers are reminded of Tashkent, Muslims are teased about pork in their soup, and Buddhists for their pacifism. As infantryman Gerts Rogovoi put it, "where the frontline ends, nonsense begins." ${ }^{65}$ Emerging from these recollections is a particular kind of discrimination against Jewish soldiers - the so-called "award-antisemitism" ("nagradnoi" antisemitizm) - which saw these men habitually excluded from award lists and decorations. The view that the Jewish position in the Soviet Union became significantly more precarious after the war is underscored by the fact that more weight is placed by interviewees on what happened after 1945 than on what occurred during the war. The campaign against cosmopolitism, the Doctors' Plot, the inability to secure access to the education or employment, and in many instances the inability to continue to advance in their military careers all feature strongly in the recollections of numerous veterans. $^{66}$

\section{Managed Memory}

The social memory of the war which iremember.ru conserves and promotes, then, is far from monolithic, uncritical, or bombastic. In demonstrating the complex experiences of ordinary people in extreme situations, the database thus reveals the tension that exists between historical myth, which is linear and does not tolerate ambiguities, and social memory, which is by contrast fragmented and shot through with grey areas. That the state now embraces these narratives, and indeed provides funding for the website, shows how far

64 Uritskii Isaak Izrailevich, https://iremember.ru/memoirs/tankisti/uritskiy-isaak-izrailevich/.

65 Rogovoi Gerts Moiseevich, http://iremember.ru/memoirs/pekhotintsi/rogovoy-gertsmoiseevich/.

66 On these issues see G. V. Kostyrchenko, Tainaia politika Stalina. Vlast' i antisemitizm, Moscow 2001; Jonathan Brent and Vladimir P. Naumov, Stalin's Last Crime. The Plot against the Jewish Doctors, 1948-1953, New York 2003; Yoram Gorlizki and Oleg Khlevniuk, Cold Peace. Stalin and the Soviet Ruling Circle, 1945-1953, Oxford 2004. 
removed Putin's Russia is from the late Soviet Union. Under Khrushchev, even seemingly tame issues led to howls of disgust from officials. When war veteranturned-movie-director, Grigorii Chukhrai, included a scene in his "Ballad of a Soldier" (Mosfil'm, 1959) in which Red Army soldiers hand over the unit's soap as a present for the wife of one of them, the Minister of Culture complained. Without soap, the soldiers could not wash. Hence it followed "that our army is unclean" (Sledovatel'no, nasha armiia nechistoplotna) - an insult to the armed forces! The film was released, but could not be shown in the major capitals of the Union. Under Brezhnev, things got worse: Chukhrai's attempt to produce a film on Stalingrad was blocked by the military, whose propagandists had no interest in the "truth of the trenches" (okopnaia pravda) but wanted more uplifting fare. ${ }^{67}$ Chukhrai's plans did not include anything of the kind iremember.ru makes publicly available with the help of government funding. Needless to say, none of this content could ever have been published, let alone promoted at any point in time before perestroika.

In terms of memory, then, Putin's Russia is not the Soviet Union. Indeed, this statement is true in a broader sense. Call it "managed democracy" 68 or "competitive authoritarianism," 69 while the Russian political system today cannot be described, with a straight face, as "democratic," it is no totalitarian dictatorship either. ${ }^{70}$ In the sphere of the politics of history, rather than totalitarian control of the narrative, we can observe the management of memory - a technique that works in two ways. First, there is the threat of prosecution under the memory law, made explicit through exemplary legal action against individuals. ${ }^{71}$ The memory law serves the function of the random repression of dissidents. It serves to guard against exploitation of this source to its full extent, while being unable to prevent such use.

There is also a slow process of alignment between the fragmented and untidy social memory of iremember.ru and the more polished official memory - a process made possible by the partial overlap between the two, along with the financial and symbolic incorporation of Drabkin's project into mainstream culture. Patriotism is common both to the official narrative and to social memory, and therefore facilitates a space of consensus between the state and society. The landing page for iremember.ru is now dominated by a banner that reads "What will you do so that your grandchildren will be proud of you the

67 Grigorii Chukhrai, Moe kino, Moscow 2002, pp. 132 f. and pp. $191-193$.

68 Ivan Krastev and Stephen Holmes, An Autopsy of Managed Democracy, in: Journal of Democracy 23. 2012, no. 3, pp. 33-45.

69 Steven Levitsky and Lucan Way, The Rise of Competitive Authoritarianism, in: Journal of Democracy 13. 2002, no. 2, pp. $51-65$.

70 Timothy J. Colton, Russia. What Everyone Needs to Know, Oxford 2016, pp. 145 - 150; Łukasz Kondraciuk, Is Putinism Sustainable?, in: New Eastern Europe 31. 2018, pp. $21-26$, here p. 23.

71 See Edele, Fighting Russia's History Wars; and the update in id., Debates on Stalinism, Manchester [2020]. 
way we are proud of our heroic grandparents?!" This slogan echoes the logic underpinning official efforts to link different generations through the heroic narrative. The 2014 Valdai report, for example, stressed the importance of making history personal, so that the younger generation would be able to connect with and become part of the historical narrative through the stories of their grandparents. ${ }^{72}$ A similar logic underpins interviews with Soviet veterans who are part of the online project War Witness: Heritage. ${ }^{73}$ These interviews include a brief account of the war by a veteran, which is then augmented with commentary from their children or grandchildren, who discuss what the experience of their elders means for them. It is here that consensus on patriotism and the belief that patriotic education should be the basis for Russia's future is reached, and that the disparate memories within iremember.ru are brought together. Furthermore, by allowing uncomfortable historic episodes to enter the mainstream narrative under the banner of patriotism, the ability of counter-narratives to detract from the official story is defused.

We can also observe considerable self-alignment of interviewees with the official narrative. Self-censorship, while clearly lessened, is still in evidence. Interviewees frequently cut off the conversation when sticky topics - such as executions or rapes - are raised. They note that all manner of things happened during the war, and that sharing these stories with non-veterans is meaningless because those who have not experienced the war for themselves would simply never understand. ${ }^{74}$ The contrast between Russian veterans interviewed in the Russian Federation and Jewish veterans interviewed in Israel is instructive in this regard. The latter are much more forthcoming and much less inhibited by implicit taboos than the former. ${ }^{75}$

A particularly intriguing case is offered by the comparison of the interviews with Ion Degen and Marat Kalinenok. ${ }^{76}$ Both men share similar backgrounds:

72 Valdai Discussion Club, National Identity, p. 16 and pp. $43 \mathrm{f}$.

73 War Witness: Heritage, http://catalog.rt.com/en/series/war-witness-heritage/.

74 See in particular interview with Iosif Mironovich Iampol'skii, https://iremember.ru/ memoirs/tankisti/yampolskiy-iosif-mironovich/; Aleksandr Mikhailovich Aronas, https://iremember.ru/memoirs/tankisti/aronas-aleksandr-mikhaylovich/; Georgii Nikolaevich Krivov, https://iremember.ru/memoirs/tankisti/krivov-georgiy-nikolaevich/; Arkadii Grigor'evich Vesterman, https://iremember.ru/memoirs/tankisti/vestermanarkadiy-grigorevich/.

75 The Israeli testimonies can be accessed by searching the website for their interviewer, G. Koifman. On Jewish Red Army testimony see also Feferman, “The Jews' War," pp. $574-590$.

76 Degen Ion Lazarevich, http://iremember.ru/memoirs/tankisti/degen-ion-lazarevich/; Kalinenok Marat Aleksandrovich, https://iremember.ru/memoirs/tankisti/kalinenokmarat-aleksandrovich/. Ion Degen also published a number of books of recollections as well as poetry, including: Ion Degen, Voina nikogda ne konchaetsia. Rasskazy, dokumental'naia proza, stikhi, Israel 1995, http://lib.ru/MEMUARY/1939-1945/ DEGEN/wojna.txt. He is also focus of the Russian documentary film "Degen" (2014). 
both were tank aces; both entered the war as committed Communists; and both were educated young men who would receive their doctorates in the years after the war - Degen in medical sciences, and Kalinenok in history. While they did not know each other, their wartime biographies are nearly parallel. The main difference is that Degen is Jewish and interviewed in Israel, where he emigrated in 1977. Despite a fairly transnational Soviet identity, Kalinenok identifies as Russian: "my first name is French, my last name Belarusian, I was born in Tataria, and am myself a Russian."

Kalinenok read the transcript of Degen's interview, and responded directly:

Look, how much we had in common. But for some reason, we have a completely different appreciation of these events. In his interview, everything is gloomy, everything is bad, everybody retreated, fled. Everything is recounted in dark tones, even the communist regime $[\ldots]^{77}$

The differences are indeed striking, with Degen's breaking completely with the official Soviet and now Russian war-story and Kalinenok writing himself into it.

Degen's account of the start of the war evokes a scene of total chaos, mass desertion and destruction. His battalion very quickly gave in to the German advance, after falling into encirclement. While his comrades dispersed among the local civilian population, for the next 19 days Degen, suffering a festering leg wound, and his friend Sasha fought their way east to cross the frontline. Degen's Communist strength and belief in the supremacy of the Soviet power were seriously tested at his crossing of the Dnieper River, during which he lost the sight of Sasha. Having swum across the river, the 16-year-old broke down in tears; he had been told that "on the third day of war we'd be in Berlin welcomed with flowers by the teary-eyed German proletariat," yet here he was - cold, hungry, wounded, separated from his friend who he presumed dead (the two men would, however, meet again in 1945), with no weapon, and completely disoriented by the fact that something like this could ever have happened.

Degen tells of mass desertions from the frontline in the Caucasus, complete German domination on the battlefield and the impossibility of holding back their advances, as well as the difficulty of fighting in a region in which the local population was openly hostile to the Soviet army. The bane of hunger is a prominent feature of his account; indeed, it is the cause of his arrest by the NKVD following an incident in which he was accused of black-market dealing. Yet luck seems to have been on Degen's side throughout the war, and he would be delivered from the NKVD prison, leaving behind fellow soldiers who were yet to face their punishment for tearing off their military insignias while breaking out of an encirclement, dropping their weapons while retreating, or

77 Kalinenok Marat Aleksandrovich, https://iremember.ru/memoirs/tankisti/kalinenokmarat-aleksandrovich/. 
returning alive from German captivity. Hunger, in Degen's words, was used in his tank training school to stimulate "in the most sadistic manner" the desire by soldiers to get to the frontline, where they would receive marginally better food rations. Degen has little praise for the command in general, who are described as being the root cause of military demoralization, and totally unprepared for combat. For Degen, the command would use the most sadistic tactics to preserve discipline, while themselves being total cowards, shamelessly attempting to use vehicles to evacuate their families and their home furniture, and ignoring pleas to help transport wounded soldiers.

Degen does not hold back in describing the abuse of alcohol on the front, remembering an occasion when he missed, to his great regret, the opportunity to meet writer Ilya Ehrenburg who was visiting soldiers on the front, because Degen was embarrassed by how much he reeked of vodka. He also recalls being so inebriated during his last combat episode in Prussia that when he was wounded, his own blood smelled of vodka. Similarly, he speaks freely about his hatred of the enemy, admitting to various mistreatments of POWs; he notes that the concept of humanity during the war was something that was hard to define. This is quite uncommon among the interviews - generally while subjects will admit to having hated the enemy, veterans usually recall that German POWs were left alone. $^{78}$

Kalinenok was, like Degen, raised in a family with strong Communist beliefs - best reflected in his parents' choice to name the boy after Jean-Paul Marat. Yet Kalinenok's descriptions of his wartime experience are indeed painted in different colors to Degen's: here the army does not desert or run away but retreats and his battalion commanders did not transport their wives and potted plants in military vehicles, but fought shoulder to shoulder with the rank and file. The high number of volunteers is a proof for him that people were not coerced and made to fight through fear. Kalinenok does not believe in tears, he never experienced fear on the battlefield and his belief in the ultimate victory was unwavering. Degen's account of fear, by contrast, is disarming in his admission that he was a coward and like anyone just hoped to make it alive out of the war - though he would never allow this to show, and he quickly learned how to best manage his fears so that others would not label him as "evrei-trus." On the question of food supplies, Kalinenok notes that the problem was not a lack of food, but simply that young males hard at work would always demand more food no matter how plentiful it may have been. Where Degen notes that there were no atheists on the frontline and recalls seeing fellow soldiers pray before battle, Kalinenok does not remember any manifestations of religious belief in his unit. Similarly, where Degen acknowledges a number of superstitions among tank crew members (including the bad luck that would befall the crew if a woman were to touch the tank),

78 On this issue see Mark Edele, Take (No) Prisoners! The Red Army and German POWs, $1941-1943$, in: The Journal of Modern History 88. 2016, pp. $342-379$. 
and carried a lucky pen as a talisman that would bring him good fortune in combat, Kalinenok does not account for any forms of superstition on the front. While the enemy is hated during the battle, POWs are left alone; the drinking here occurs in moderation, and only after combat, with no drunkards featuring in Kalinenok's recollections. In contrast to Degen's accounts of "award-antisemitism," Kalinenok describes a complete lack of envy when a fellow soldier received an award and overall happiness for someone else's recognition.

In response to the interviewer's "provocative question," as Kalinenok describes it, of whether the army fought with excessive losses, he insists that at the time he was too young to be able to make a judgment of that kind. A Party member since 1946, when asked the central question of the project of how he felt about Stalin and the Party, he says that he feels like most of the country in that Stalin played a key role in securing the victory. Kalinenok is scathing of the books and films that have appeared in recent times that depict the military command and NKVD / SMERSH officers in the most negative light, and give a sense that the army was full of traitors, thieves, cowards and scoundrels. $\mathrm{He}$ accuses all these "authors" of deliberately and provocatively seeking to show that everything was bad during Soviet power.

Whether or not Kalinenok aligned himself consciously with a more airbrushed version of this war, or whether Degen's account is informed by hindsight - as Kalinenok suggests - readers of iremember.ru will be able to use this source to support two strikingly different versions of the same war, one undermining the national memory's master narrative, the other stabilizing it.

Another form of self-alignment is less conscious, but still considerable, as can be seen in the answers to two questions put to every veteran interviewed for the website: whether the veterans believed that the losses suffered by the Soviet Union were excessive, and what they thought of Stalin and the Party. Usually these questions seek a response as to whether the veterans believed Stalin played a key role in securing victory during the war, and whether the veterans felt at any point that the Soviet Union would be defeated by Germany. These are questions which transcend the individual horizon of personal experience. Moreover, they are highly charged in the current political climate. Even an impressionistic overview of the responses given by veterans demonstrates a strong presence of the idea that Stalin played a key role in winning the war. As to whether they thought at the time that victory could have been achieved with fewer losses, veterans are upfront about the fact that this was not something they were thinking about as they were very young, and that they probably would not have known enough to pass judgment one way or another. Infantryman Kirill Gadzhii notes that at the time this was not a topic at all, as regular soldiers did not know very much about the overall situation and that it 
would be hard now to talk about these events and decisions objectively. ${ }^{79}$ In a similar vein, when asked whether he thought the Soviets might lose the war, artilleryman Vladimir Maksimov observes that he was too young to have had thoughts of any kind: "I was only 18, just a kid, what thought could I have had? At this age, perhaps I would question things, but not as an 18-year-old boy..." While the collection does include accounts by veterans who strongly believe that the people were used as cannon fodder due to Stalin's brutal, Tsar-like mentality and the utter incompetence of the military command, there is generally strong consensus on Stalin's crucial role in securing victory. ${ }^{81}$

In most instances, veterans note that they viewed Stalin in an extremely positive light during the war, and even when they became aware of the full details of the wartime horrors, they never really connected this situation with Stalin. Indeed, irrespective of whether they changed their opinion of him later - especially after the twentieth Party Congress - the central role of Stalin during the war is still acknowledged. Moreover, what emerges from these accounts is a perception of stability during Stalin's rule and, more importantly, his personal modesty: veterans repeatedly cite his humble background and home in Gori, his modest clothes and the fact that he only had 17 rubles in his account when he died (a fact that veterans compare favorably to the financial standing of Russia's current-day political and business elites). ${ }^{82}$ These responses resonate with what some historians have identified as a trend towards re-Stalinization within Russian society. ${ }^{83}$ While individual accounts subvert this trend, many others further it. The investment of the Russian state in a website promoting the social memory of the war has thus paid off.

79 Gadzhii Kirill Trofimovich, http://iremember.ru/memoirs/pekhotintsi/gadzhiy-kirilltrofimovich/.

80 Maksimov Vladimir Petrovich, http://iremember.ru/memoirs/artilleristi/maksimovvladimir-petrovich/.

81 Kuz'michev Nikolai Alekseevich, http://iremember.ru/memoirs/samokhodchiki/kuzmi chev-nikolay-alekseevich/; Ariia Semen L'vovich, http://iremember.ru/memoirs/tankisti/ ariya-semen-lvovich-mekhanik-voditel-tanka-t-34/; Rod'kin Arsenii Konstantinovich, http://iremember.ru/memoirs/tankisti/rodkin-arseniy-konstantinovich/; Tolstikov Vladimir Vladimirovich, http://iremember.ru/memoirs/tankisti/tolstikov-vladimir-vladimi rovich/.

82 Rassadnikov Mikhail Ivanovich, http://iremember.ru/memoirs/samokhodchiki/rassad nikov-mikhail-ivanovich/; Tal'skii Mikhail Nikolaevich, http://iremember.ru/memoirs/ artilleristi/talskiy-mikhail-nikolaevich/; Larin Aleksandr Vasil'evich, http://iremember. $\mathrm{ru} /$ memoirs/letno-tekh-sostav/larin-aleksandr-vasilevich/.

83 Oleg Khlevniuk, Stalin. New Biography of a Dictator, New Haven 2015, pp. 329 f; Khapaeva, Triumphant Memory. 


\section{The Memory Revolution in the Digital Age}

Since glasnost, and even more so since the breakdown of the Soviet Union, a large number of memoirs, autobiographical accounts, and oral histories have entered the public sphere. In particular, the history of the Second World War has seen a boom in the publication of such egodocuments. Some historians see this proliferation of accounts as a "memory revolution." These new sources, the argument goes, are as revolutionary a change in the source base as the "archival revolution" prompted by the opening of many Soviet government depositories. ${ }^{84}$ Can this view be sustained, given the evidence of self-censorship and government management of memory, and of self-alignment with the official view of the war?

The answer is a qualified yes. Clearly, the war as remembered by the veterans interviewed by Drabkin and his team is much more complex, messy, and personal than anything published during Soviet times, such that iremember.ru presents a much more multi-faceted and detailed view of the war. For every case of self-censorship, one can find others which assert the phenomenon in question. The presence of a substantial minority of Israeli interviewees is particularly valuable in this respect. At the same time, of course, the sources need to be read critically; they should not form the only source historians use, but should be triangulated by others wherever possible. Meanwhile, future research will need to explore to what extent the hardening stance of the Putin government on the memory of the Second World War will increase selfalignment and self-censorship among future interviewees.

Dr. Iva Glisic, The University of Western Australia, Faculty of Arts, Business, Law and Education, School of Humanities, 35 Stirling Highway, 6009 Perth, Australia E-Mail: iva.glisic@uwa.edu.au

Prof. Dr. Mark Edele, The University of Melbourne, Faculty of Arts, School of Historical and Philosophical Studies, Arts West, West Wing, 3010 Parkville, Victoria, Australia

E-Mail: mark.edele@unimelb.edu.au

84 Mark Edele, Review of: Rebecca Manley, To the Tashkent Station. Evacuation and Survival in the Soviet Union at War, Ithaca 2009, in: The Journal of Modern History 83. 2011, pp. 233 -235, here p. 234 (“memory revolution"); Oleg Budnitskii, The Great Patriotic War and Soviet Society. Defeatism, 1941-42, in: Kritika. Explorations in Russian and Eurasian History 15. 2014, pp. 767-797, here p. 777 ("revolution of memory"); id., A Harvard Project in Reverse. Materials of the Commission of the USSSR Academy of Sciences on the History of the Great Patriotic War. Publications and Interpretations, in: Kritika. Explorations in Russian and Eurasian History 19. 2018, pp. $175-202$, here p. 176 (with reference to iremember.ru). On the archival revolution see Sheila Fitzpatrick, Impact of the Opening of Soviet Archives on Western Scholarship on Soviet Social History, in: Russian Review 74. 2015, pp. $377-400$. 